\title{
ANALISIS KESALAHAN SISWA DALAM MENYELESAIKAN SOAL CERITA BERDASARKAN ANALISIS NEWMAN DI KELAS X SMA INTENSIF TARUNA PEMBANGUNAN SURABAYA
}

\author{
Moh.Syukron Maftuh \\ Fakultas Keguruan dan Ilmu Pendidikan, Universitas PGRI Adi Buana Surabaya \\ syukron@unipasby.ac.id
}

\begin{abstract}
Abstrak
Penelitian ini merupakan penelitian deskriptif dengan pendekatan kuantitatif. Subjek penelitian ini adalah 34 siswa kelas X MIA 2 SMA Intensif Taruna Pembangunan tahun ajaran 2019/2020 yang kemudian diberikan tes tertulis berupa soal cerita dan di ambil 3 siswa yang melakukan kesalahan terbanyak untuk dilakukan wawancara. Kemudian data yang diperolah dilakukan reduksi data, penyajikan data dalam bentuk tabel untuk dideskripsikan yang kemudian diambil kesimpulan. Berikut berdasarkan hasil analisis data diperoleh hasil penelitian bahwa (1) Pada tahap membaca siswa tidak mengalami kesulitan, sehingga tidak ada kesahan pada tahap membaca. (2) Pada tahap memahami, kesalahan yang dilakukan siswa sebanyak $37.15 \%$. yang meliputi kesalahan pada saat mengidentifikasi perintah pada soal, sehingga salah dalam menentukan apa yang diketahui dan apa yang ditanyakan dalam soal serta melakukan kesalahan dalam mengubah konteks masalah soal cerita menjadi bahasa sendiri yang berpengaruh pada proses penyelesaian soal, (3) Pada tahap transformasi, kesalahan yang dilakukan siswa sebanyak $13.04 \%$. yang meliputi siswa tidak dapat menerjemahkan kesalahannya dan mentransformasi formasi yang ada pada soal ke dalam bentuk kalimat matematika, serta kurangnya pemahaman untuk menggunakan metode yang akan digunakan. (4) Pada tahap ketrampilan proses, kesalahan yang dilakukan siswa sebanyak 20.94\%. yang meliputi siswa masih melakukan kesalahan dalam proses perhitungan, diantaranya pada saat memindahkan suku ke ruas yang berbeda serta dalam menjumlahkan dua suku yang variabelnya sama. Selain itu siswa juga melakukan kesalahan dalam proses eliminasi dan substitusi yaitu ketika melakukan operasi perkalian, penjumlahan, dan pengurangan serta kurangnya pemahaman operasi apa yang akan digunakan. Dan (5) pada tahap penulisan jawaban akhir, kesalahan yang dilakukan siswa sebanyak $28.85 \%$. yang meliputi siswa tidak menuliskan kesimpulan dari solusi yang diperoleh dengan tepat, bahkan sebagian siswa tidak mengubah solusi yang diperoleh ke dalam bentuk kalimat sesuai dengan permasalahan nyata yang diketahui pada soal
\end{abstract}

Kata Kunci : Kesalahan Menyelesaian Soal, Soal Cerita, Analisis Newman.

\section{Abstract}

This research is a descriptive study with a quantitative approach. The subjects of this study were 34 students of class X MIA 2 SMA Taruna Pembangunan Intensive School academic year 2019/2020 who were then given a written test in the form of a story, and 3 students who made the most mistakes were taken to be interviewed. Then the data obtained were carried out to have data reduction, data presentation in tabular form to be described, and then conclusions were drawn. Based on the results of data analysis, it was obtained that (1) At the reading stage, students did not experience difficulties, so there was no error at the reading stage; (2) In the stage of understanding, mistakes made by students were $37.15 \%$ which included errors when identifying commands on the problem, so it was wrong in determining what was known and what was asked in the problem and making mistakes in changing the context of the problem of the story into its own language that affected the process of problem solving; (3) At the transformation stage, the errors conducted by students were $13.04 \%$ including students were unable to translate their mistakes and transform the existing formations in the problem into the form of mathematical sentences, as well as a lack of understanding to use the method to be used; (4) In the process skills stage, the mistakes made by students were $20.94 \%$ including students still made mistakes in the calculation process such as when transferring terms into different segments and adding two terms with the same variable. In addition, students also made mistakes in the process of elimination and substitution when performing multiplication, addition, and subtraction operations as well as lack of understanding of what operations would be used; and (5) At the stage of writing the final answer, the mistakes made by students were $28.85 \%$ including students did not write the conclusions of the solutions obtained correctly, even some students did not change the solutions obtained in the form of sentences in accordance with the real problems known in the tests.

Keywords: Mistakes in Solving Problems, Problem Questions, Newman Analysis. 


\section{PENDAHULUAN}

Mengingat pentingnya pelajaran metematika bagi berlangsungnya kehidupan, maka setiap siswa diwajibkan untuk menguasai konsep-konsep dasar matematika dan tentunya lebih dalam lagi siswa di wajibkan dapat menyelesaikan soal cerita yang berkaitan dalam kehidupan sehari-hari.Menurut Rokhimah (2015), berdasarkan wawancara peneliti dengan guru matematika SMPN 1 Bulus pesantren Kebumen menunjukkan bahwa secara umum kemampuan siswa SMPN 1 Bulus pesantren untuk menyelesaikan soal cerita keberhasilannya belum mencapai 50\%. Hal tersebut sesuai dengan penelitian yang dilakukan oleh Trapsilo (2016) bahwa masih banyak siswa yang mengalami kesulitan dalam menyelesaikan soal cerita. Berdasarkan penelitian tersebut sangat sesuai dengan pengalaman peneliti pada saat melakukan observasi di SMA Intensif Taruna Pembangunan di kelas X MIA 2 bahwa siswa masih kurang menguasai tentang soal cerita pada materi sistem persamaan linier tiga variabel, khususnya siswa tidak mampu memahami maksud dan permasalahan soal (diketahui dan ditanya), mengubah soal cerita ke dalam bentuk matematika (transformasi), proses perhitungan (proses Skil), dan penulisan jawaban akhir yang digunakan pada materi sistem persamaan linier tiga variabel.

Menurut Hartini (dalam Haryati, 2015) soal cerita merupakan salah satu bentuk soal yang menyajikan permasalahan terkait dengan kehidupan/sehari-hari dalam bentuk cerita. Soal cerita merupakan soal yang dapat disajikan dalam bentuk lisan maupun tulisan. Soal cerita yang berbentuk tulisan berupa sebuah kalimat dan pertanyaan ataupun yang mengilustrasikan kegiatan dalam kehidupan sehari-hari”.

Pada penelitian ini, analisis Newman menjadi dasar dilakukannya penelitian untuk mengetahui jenis kesalahan yang dilakukan oleh siswa. Dalam teori Newmen ini dapat membuat siswa semakin berhati-hati dan lebih fokus pada saat mengenali tahapan yang tepat dalam proses menyelesaikan masalah. Selain itu, teori Newman dapat menjadi sebuah garis besar dan skema kerja yang teratur sehingga dapat memudahkan siswa dalam menyelesaikan mesalah. Tahap penyelesaian masalah pada teori Newman akan menjadi sebuah opsi yang menarik dan memudahkan siswa dalam menyelesaikan masalah. Tahap penyelesaian masalah pada teri Newman adalah membaca, pemahaman, transformasi, keterampilan proses, dan penulisan jawaban akhir. Sehingga melalui analisis Newman ini setiap kesalahan-kesalahan yang dilakukan oleh siswa dapat di kurangi bahkan semakin sedikit siswa yang melakukan kesalahan. Adapun indikator kesalahan yang di lakukan oleh siswa seperti yang di ungkapkan oleh Jha dkk (dalam Rokhimah , 2015:13) adalah sebagai berikut:

\section{Indikator Kesalahan Newman}

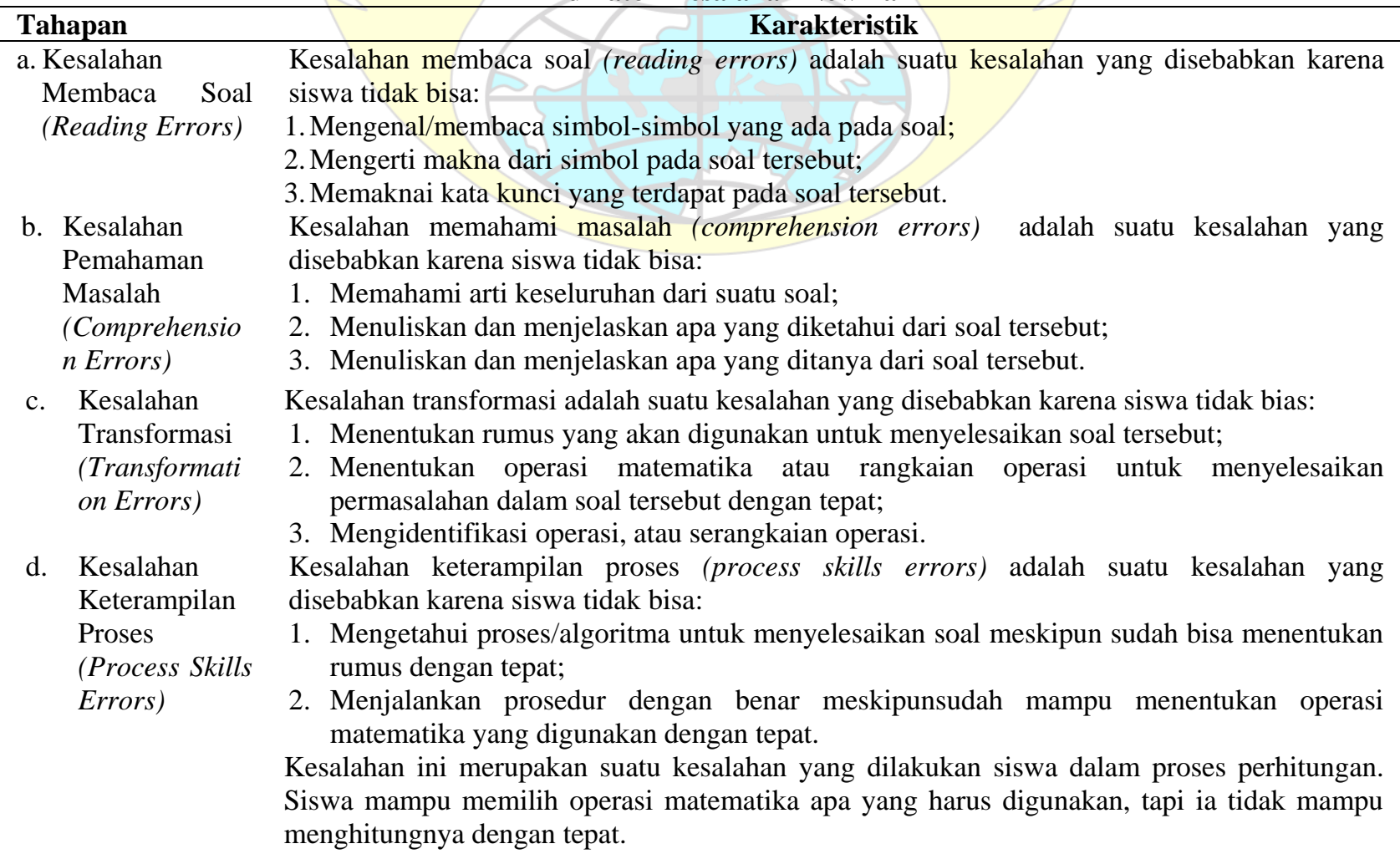




\begin{tabular}{|c|c|}
\hline Tahapan & Karakteristik \\
\hline $\begin{array}{l}\text { e. Kesalahan } \\
\text { Penulisan } \\
\text { Jawaban } \\
\text { Akhir } \\
\text { (Encoding } \\
\text { Errors) }\end{array}$ & $\begin{array}{l}\text { Kesalahan penulisan jawaban (encoding errors) adalah suatu kesalahan yang disebabkan } \\
\text { karena siswa tidak bisa: } \\
\text { 1. Menuliskan jawaban yang ia maksudkan dengan tepat sehingga menyebabkan berubahnya } \\
\text { makna jawaban yang ia tulis; } \\
\text { 2. Mengungkapkan solusi dari soal yang ia kerjakan dalam bentuk tertulis yang dapat } \\
\text { diterima; } \\
\text { 3. Menuliskan kesimpulan dengan tepat hasil pekerjaannya. }\end{array}$ \\
\hline
\end{tabular}

Menurut Kamus Besar Bahasa Indonesia (Online) "kesalahan adalah menyimpang dari yang seharusnya." Setiap individu pasti pernah mengalami kesalahan, baik kesalahan yang disebabkan dari faktor intern maupun faktor ekstern. Demikian halnya, kesalahan-kesalahan tersebut tidak hanya dialami oleh siswa yang berkemampuan dibawah rata-rata, bahkan siswa yang dikategorikan dengan kemampuan diatas rata-rata tidak jarang mengalami kesalahan dalam mengerjakan soal-soal cerita. Contoh kesalahan yang dialami oleh siswa adalah siswa melakukan kesalahan dalam memahami dan mengubah permasalahan yang berbentuk kalimat yang kemudian harus diubah sesederhana mungkin kedalam bentuk matematika.

Sehingga dapat disimpulkan kemampuan siswa dalam menyelesaikan soal cerita yang berkaitan dalam kehidupan belum bisa dikatakan maksimal. Hal tersebut disebabkan karena adanya anggapan dari sebagian besar siswa yang merasa pelajaran matematika dikategorikan sabagai pelajaran yang sulit, menakutkan dan memerlukan tingkat pemikiran yang lebih untuk mempelajarinya. Dalam hal ini sebagian besar siswa masih mengalami kesalahan dalam menyelesaikan soal cerita pada sub materi Sistem Persamaan Linear Tiga Variabel. Kesalahan-kesalahan yang dilakukan siswa di latar belakangi oleh kondisi dari masing-masing individu.

Untuk itu perlu adanya tindakan untuk mempersempit kesalahan yang dilakukan oleh siswa. Kesalahan yang dialami siswa dalam mengerjakan soal cerita menjadi salah satu tolak ukur untuk mengetahui sebarapa jauh siswa tersebut menguasai konsep-konsep dasar dalam pelajaran matematika khususnya pada soal cerita materi sistem persamaan linier tiga variabel berdasarkan analisis Newman.

Oleh karena itu peneliti tertarik menganalisis kesalahan-kesalahan berdasarkan analisis Newman yang dialami oleh siswa dalam menyelesaikan soal cerita khususnya pada materi Sistem Persamaan Linear Tiga Variabel, sehingga peneliti tertarik melakukan penelitian dengan judul "Analisis Kesalahan Siswa dalam Menyelesaikan Soal Cerita Berdasarkan Analisis Newman di Kelas X SMA Intensif Taruna Pembangunan Surabaya"

\section{METODE PENELITIAN}

\section{Jenis penelitian}

Tujuan penelitian ini adalah untuk mendeskripsikan kesalahan-kesalahan yang dilakukan oleh siswa serta untuk mengetahui persentase kesalahan siswa pada saat menyelesaikan soal cerita pada materi Sistem Persamaan Linier Tiga Variabel berdasarkan analisis Newman sehingga jenis penelitian yang digunakan adalah penelitian deskriptif dengan pendekatan kuantitatif

\section{Data dan Sumber Data}

\section{a. Data}

Pada penelitian ini data yang diperoleh dihasilkan dari hasil tes yang dilakukan serta wawancara dengan siswa terpilih sebagai subjek dengan kriteria melakukan kesalahan terbanyak yang mewakili 4 jenis kesalahan Newman. 4 jenis kesalahan Newman yang dimaksudkan yaitu kesalahan pemahaman, kesalahan transformasi, kesalahan keterampilan proses, dan kesalahan pengkodean (jawaban akhir), dan memiliki jawaban yang unik dan berbeda pada saat menyelesaikan soal cerita pada materi Sistem Persamaan Linier Tiga Variabel. Dalam hal ini data dari jawaban yang unik dan berbeda tersebut diambil dari proses menganalisis hasil tes siswa. Kemudian peneliti melakukan analisis hasil tes dengan menggunakan analisis Newman.

\section{b. Sumber Data}

Sumber data pada penelitian ini diperoleh dari siswa kelas X MIA 2 SMA Intensif Taruna Pembangunan Surabaya tahun ajaran 2018/2019. Pengambilan data yang digunakan dalam penelitian ini di ambil semua siswa dalam kelas tersebut yang berjumlah 34 siswa. Pengambilan data dari 34 siswa dalam satu kelas tersebut di harapkan dapat memberikan data yang real tanpa rekayasa dan tanpa melihat kemampuan

\section{Instrumen penelitian}

Instrumen penelitian yang digunakan oleh peneliti yaitu lembar tes tertulis berupa soal uraian yang berbentuk soal cerita pada materi sistem persamaan linear tiga variabel dan juga lembar pedoman wawancara berdasarkan analisis Newman. 


\section{Teknik pengumpulan data}

Teknik pengumpulan data yang dilakukan dalam penelitian ini adalah dengan metode tes dan wawancara. Adapun langkah-langkah pengumpulan data menggunakan teknik tes adalah menentukan batasan materi, menentukan kisi-kisi soal, menentukan jenis dan bentuk soal, menentukan waktu tes, menentukan jumlah soal, memberikan soal tes kepada subyek penelitian, melakukan pengawasan jalannya tes dan memeriksa hasil tes sedangkan adapun langkah-langkah dalam wawancara adalah memilih subyek wawancara, menentukan pokokpokok permasalahan (topik), menentukan waktu wawancara, melakukan wawancara, mencatat hasil wawancara dan mengidentifikasi hasil wawancara

\section{Teknik analisis data}

Teknik analisis data yang digunakan dalam penelitian ini menggunakan model Miles dan Huberman, yaitu reduksi data, penyajian data dan penarikan kesimpulan.

\section{a. Reduksi Data}

Adapun tahapan reduksi data pada penelitian ini adalah memberikan tes, memeriksa hasil tes, memilih subyek wawancara dengan kategori melakukan kesalahan terbanyak sesuai prosedur Newman, yaitu kesalahan membaca, pemahaman, kesalahan transformasi, kesalahan keterampilan proses, dan kesalahan penulisan jawaban akhir, memilih pokok-pokok hasil tes yang merupakan data umum untuk kemudian menjadi pokok bahasan dalam wawancara, melakukan wawancara dengan subyek terpilih (melakukan kesalahan terbanyak), mencatat hasil wawancara untuk disederhanakan dan membuat catatan lapangan

\section{b. Penyajian Data}

Setelah data direduksi, maka langkah selanjutnya adalah mendisplaykan data yang berbentuk uraian singkat, bagan, hubungan antar kategori, flowchart dan sejenisnya. Dalam penelitian ini data disajikan dalam bentuk teks yang bersifat naratif. Sehingga dari informasi yang diperoleh dapat dilakukan penarikan kesimpulan.

\section{c. Penarikan Kesimpulan}

Penarikan kesimpulan ini merupakan kegiatan untuk merangkum data serta memeriksa kebenaran data yang telah dikumpulkan terkait bagaimana kesalahan Siswa dalam Menyelesaikan Soal Cerita Materi Sistem Persamaan Linear Tiga Variabel Berdasarkan Analisis Newman

\section{HASIL DAN PEMBAHASAN}

Setelah peneliti menganalisa dari hasil tes siswa, dapat diketahui bahwa siswa masih banyak melakukan kesalahan dalam menyelesaikan soal cerita persamaan linear tiga variabel. Berikut tabel rekapitulasi persentase kesalahan yang dilakukan siswa disajikan pada tabel 1 sebagai berikut.

Tabel 3

Rekapitulasi Persentase Kesalahan Siswa

\begin{tabular}{clc}
\hline No & \multicolumn{1}{c}{ Jenis Kesalahan } & Persentase \\
\hline 1 & Pemahaman & $37.15 \%$ \\
2 & Transformasi & $13.04 \%$ \\
3 & Keterampilan Proses & $20.94 \%$ \\
4 & Penulisan Jawaban Akhir & $28.85 \%$ \\
\hline
\end{tabular}

Dari Tabel 1 terlihat bahwa paling banyak kesalahan yang dilakukan oleh siswa terjadi pada tahap pemahaman yaitu sebesar $37.15 \%$. Kesalahan pada tahap pemahaman sangat berpengaruh pada proses pengerjaan soal pada tahap selanjutnya, hal ini dikarenakan pada tahap pemahaman siswa dituntut untuk mengerti dan memahami maksud dan tujuan yang ada pada permasalahan soal yaitu berkaitan dengan apa yang diketahui dan apa yang ditanyakan.

Setelah menganalisis hasil tes yang dikerjakan siswa, peneliti menentukan subjek wawancara untuk mengetahui secara langsung kesalahan-kesalahan yang dilakukan siswa dengan kriteria siswa melakukan kesalahan terbanyak berdasarkan analisis Newman. Berikut ini adalah subjek wawancara

Tabel 2

Subjek Wawancara

\begin{tabular}{c|cc}
\hline No & Nama & Kode siswa \\
\hline 1 & CGV & S01 \\
2 & DAS & S02 \\
3 & SA & S03 \\
\hline
\end{tabular}

Selanjutnya akan dideskripsikan jenis kesalahan yang dilakukan siswa dalam menyelesaikan soal cerita persamaan linier tiga variabel berdasarkan hasil analisis tes dan wawancara.

\section{Kesalahan Pemahaman}

Persentase kesalahan pemahaman yaitu sebesar $37.15 \%$ merupakan kesalahan paling tinggi diantara kesalahan-kesalahan yang lain. Berdasarkan hasil analisi tes dan wawancara, beberapa siswa melakukan kesalahan dalam menafsirkan maksud soal, kesalahan dalam menentukan apa yang diketahui danapa yang ditanyakan dalam soal, serta kesalahan dalam menghubungkan permasalahan nyata dalam model matematika berhubungan dengan persamaan linear tiga variabel. Contoh kesalahan pemahaman yang dilakukan siswa dapat dilihat pada gambar berikut. 


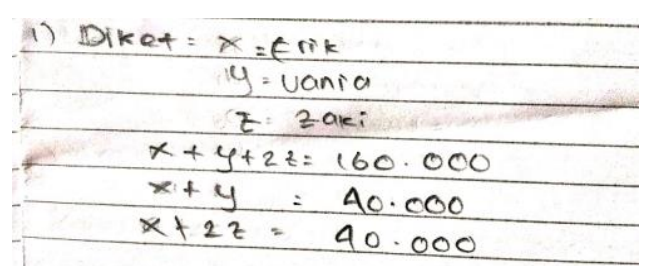

Gambar 1. Kesalahan Pemahaman siswa S03

Dari jawaban siswa pada Gambar 1 tampak bahwa siswa melakukan kesalahan dalam memahami apa yang diketahui dan ditanyakan pada soal no 1. Siswa tidak menuliskan apa yang diketahui dan apa yang ditanyakan terlebih dahulu namun langsung masuk ke tahap transformasi ke dalam bentuk persamaan. Kurangnya pemahaman siswa dalam membedakan apa yang diketahui dan apa yang ditanya dengan proses transformasi menjadi kesalahan pada tahap awal yang mengakibatkan timbulnya penafsiran baru yang tidak sesuai dengan maksud dan permaslahan pada soal. Pada akhirnya siswa pun melakukan kesalahan pada proses transformasi. Berikut petikan hasil wawancara peneliti dengan siswa S03.

Keterangan :

$\mathrm{P} \quad$ : Peneliti

SO3 : Kode Siswa

p : Mengapa kamu bisa menuliskan apa yang diketahui seperti ini?

S03 : Menurut saya yang diketahui seperti itu.

$p \quad$ : Kamu paham tidak dengan soal ini?

SO3 : insya allah

p : pada soal kan diketahui jumlah uang Erik, Vania dan Zaki Rp 160.000; kenapa kamu tuliskan menjadi $x+y+2 z=160.000$ ?

SO3 : (diam)

p : yang kamu tuliskan itu bukan yang diketahui, kamu langsung ke proses transformasi atau pemindahan ke dalam bentuk metematika. Seharusnya kamu menuliskan terlebih dahulu apa yang diketahui baru masuk ke tahap transformasi agar kamu memahami maksud dan permasalahan pada soal.

S03 : (mengangguk-angguk sambal tersenyum)

Berdasarkan hasil wawancara dengan Siswa S03 dapat diketahui bahwa siswa melakukan kesalahan dalam memahami apa maksud dan permasalahan pada soal. Penyebab siswa melakukan kesalahan karena siswa langsung masuk ke tahap transformasi tanpa menuliskan apa yang diketahui terlebih dahulu sehingga mengakibatkan kesalahan dalam menafsirkan maksud dan permasalahan pada soal.

Setelah dilakukan analisis hasil tes dan wawancara dapat disimpulkan bahwa kesalahan yang dilakukan siswa disebabkan karena:

a. Siswa tidak membaca dan memahami soal dengan teliti b. Siswa tidak menuliskan terlebih dahulu apa yang diketahui dana pa yang ditanyakan pada soal

c. Tingkat kreativitas siswa yang kurang dalam mengidentifikasi masalah nyata ke dalam model matematika.

\section{Kesalahan Transformasi}

Persentase untuk kesalahan transformasi yaitu sebesar $13.04 \%$. Berdasarkan analisis hasil tes dan wawancara, siswa melakukan kesalahan dalam menerjemahkan masalah nyata ke dalam bentuk kalimat matematika,kesalahan mentransformasikan permasalahan ke dalam bentuk persamaan yang sesuai, serta kesalahan dalam memilih prosedur matematis yang tepat untuk permasalahan yang dikemukakan dalam soal. Contoh kesalahan transformasi yang dilakukan siswa dapat dilihat pada gambar berikut.

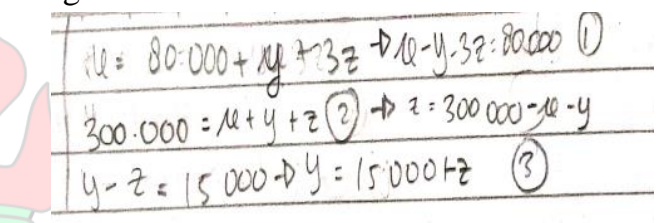

Gambar 2 Kesalahan Transformasi siswa S01

Pada Gambar 2 dapat dilihat bahwa siswa melakukan kesalahan dalam mentransformasikan apa yang diketahui ke dalam bentuk matematika, sehingga proses selanjutnya untuk mendapatkan jawaban yang tepat menjadi salah. Berikut ini disajikan petikan wawancara peneliti dengan siswa S01 untuk mengetahui penyebab kesalahan yang dilakukan.

Keterangan :

P : Peneliti

SO1 : Kode Siswa

$p$ : untuk soal no 2 kenapa kamu bias menuliskan seperti ini?

S01 : iya saya memindahkan semua variable ke sebelah kiri dan konstanta di sebelah kanan.

p : lalu kenapa di persamaan 2 tidak di rubah sama seperti persamaan 1?

SO1 : (bingung)

$p \quad$ : kemudian untuk persamaan 3 apakah sudah benar?

SO1 : sudah

p : coba baca kembali soalnya!

SO1 : iya salah. Seharusnya $R p$ 20.000; bukan $R p$ 15.000;

Berdasarkan petikan hasil wawancara tersebut dapat dilihat bahwa siswa melakukan kesalahan dalam proses transformasi. Siswa kurang memahami maksud soal dan kurang tepat dalam menuliskan dalam bentuk persamaan. Dari kesalahan tersebut siswa juga melakukan kesalahan pada tahap berikutnya, sehingga tidak dapat memperoleh dan menemukan penyelesaian yang benar. Dari hasil wawancara dapat diketahui bahwa siswa melakukan 
kesalahan karena siswa kurang memahami bagaimana membuat persamaan dari apa yang diketahui dalam soal.

Berdasarkan analisis hasil tes dan wawancara siswa dapat disimpulkan bahwa kesalahan transformasi yang dilakukan siswa disebabkan karena:

a. Kemampuan siswa yang rendah dalam mentransformasikan kata-kata ke dalam persamaan yang sesuai.

b. Siswa kurang memahami bagaimana membuat persamaan dari masalah nyata yang diketahui dalam soal.

\section{Kesalahan Keterampilan Proses}

Persentase untuk kesalahan keterampilan proses yaitu 20.94\%. Berdasarkan analisis hasil tes dan wawancara siswa, kesalahan keterampilan proses yang dilakukan siswa dalam menyelesaokan soal cerita persamaan linear tiga variable meliputi kesalahan menggunakan tanda yang tepat dalam proses perhitungan yaitu kesalahan memindahkan bilangan dan variable dari ruas berbeda, kesalahan melakukan perhitungan aljabar yaitu menjumlahkan dua variable, serta kesalahan dalam mensubstitusikan apa yang diketahui ke dalam model matematika yang tepat. Contoh kesalahan keterampilan proses yang dilakukan siswa dapat dilihat pada gambar berikut ini.

\begin{aligned} $31 e+2 y+3 z & =22000 \\$\hline $6 x+4 y+5 z & =42000 \\ & =\end{aligned}$

\section{Gambar 3 Kesalahan Keterampilan Proses S01}

Pada Gambar 3 dapat dilihat bahwa siswa S01 melakukan kesalahan dalam menggunakan operasi hitung untuk melakukan proses eliminasi sehingga hasil yang didapat menjadi salah. Hal tersebut menandakan bahwa siswa S01 Melakukan kesalahan keterampilan proses. Untuk mengetahui penyebab kesalahannya, berikut disajikan petikan hasil wawancara peneliti dengan siswa S01.

Keterangan :

$\mathrm{P} \quad$ : Peneliti

SO1 : Kode Siswa

$p \quad$ : untuk soal no 3 ini bagaimana kamu mengerjakannya dan dan mendapat hasil seperti ini?

S01 : saya mengeliminasi persamaan 1 dan 2

$p \quad$ : kalau mengeliminasi kenapa persamaan 1 dan 2 di jumlah? Kan nilainya positif semua.

S01 : diam ... tersenyum

$p \quad$ : seharusnya persamaan 1 dan 2 dikurangi karena untuk mengeliminasi variable $x$ dan $y$, sehingga dapat diperoleh nilai dari variael $z$.
Pada soal tersebut siswa melakukan kesalahan dalam melakukan proses eliminasi. Berdasarkan hasil wawancara dengan siswa dapat diketahui bahwa siswa tidak memahai bagaimana malakukan proses eliminasi untuk mendapatkan nilai dari salah satu variable. Hal tersebut disebabkan karena kemampuan siswa dalam melakukan operasi aljabar berkaitan dengan persamaan linear tiga variable masih kurang.

Berdasarkan analisis hasil tes dan wawancara siswa menunjukkan bahwa kesalahan keterampilan proses yang dilakukan siswa karena:

a. Kurangnya ketelitian siswa dalam melakukan operasi aljabar berkaitan dengan persamaan linear tiga variable.

b. Kemampuan berpikir kreatif siswa yang rendah dalam melakukan perhitungan dan menentukan perhitungan yang harus dilakukan.

\section{Kesalahan Penulisan Jawaban Akhir}

Persentase untuk kesalahan penulisan jawaban akhir yaitu $28.85 \%$. Berdasarkan analisis hasil tes dan wawancara siswa, kesalahan jenis ini banyak sekali dilakukan oleh siswa. Kesalahan yang dilakukan siswa meliputi kesalahan menyampaikan solusi yang diperoleh kedalam bentuk kalimat sesuai dengan permasalahan nyata yang dikemukakan oleh soal, kesalahan mengidentifikasi apa yang ditanyakan dalam dalam soal menjadi sebuah kesimpulan yang tepat, serta kesalahan tidak menuliskan kesimpulan dari solusi yang diperoleh. Contoh kesalahan penulisan jawaban akhir yang dilakukan siswa dapat dilihat pada gambar berikut.

$\begin{aligned} \text { Enlk } & =40.000 \\ V_{\text {ania }} & =120.000 \\ 2 \text { ala } & =120.000-40.000 \\ & =80000,00\end{aligned}$

\section{Gambar 4 Kesalahan Penulisan Jawaban Akhir S02}

Berdasarkan Gambar 4 dapat dilihat bahwa siswa melakukan kesalahan penulisan jawaban akhir. Pada jawaban tersebut siswa tidak menuliskan kesimpulan dengan benar dan lengkap dari jawaban yang diperoleh. Untuk mengetahui penyebab siswa melakukan kesalahan penulisan jawaban akhir, berikut hasil wawancara peneliti dengan siswa S02.

Keterangan :

$\mathrm{P} \quad$ : Peneliti

SO2 : Kode Siswa

p : untuk soal no 1 apakah kamu sudah selesai mengerjakan?

SO2 : sudah

p : kenapa kamu menuliskan seperti itu?

S02 : ya... hasilnya seperti itu

p : apakah hasil ini dapat menjawab apa yang 


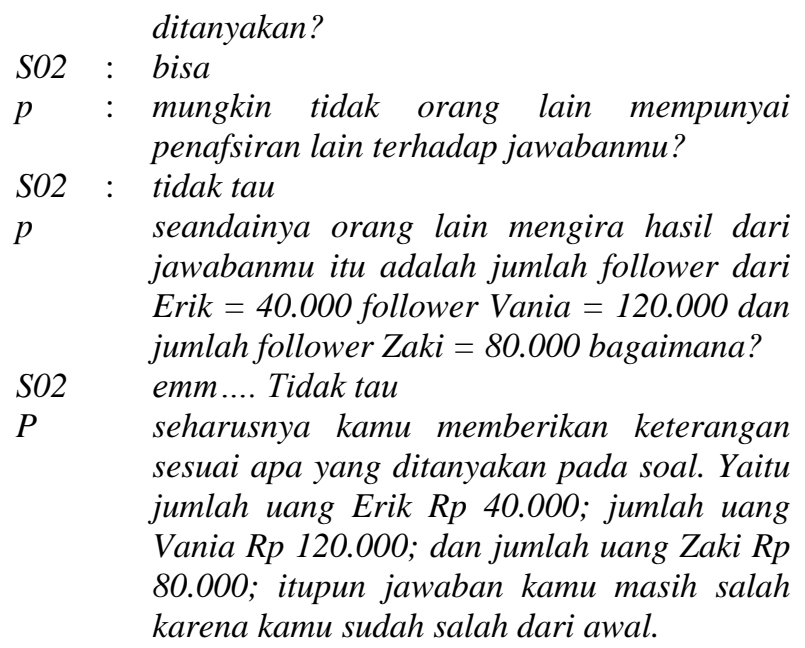

Dari petikan hasil wawancara tersebut, siswa melakukan kesalahan karena kurang memahami dan kurang teliti apa yang ditanyakan pada soal. Siswa hanya menuliskan nama dan hasil tanpa memberikan keterangan yang jelas dari nama dan hasil tersebut, sehingga dapat menimbulkan penafsiran lain yang salah dari apa yang ditanyakan pada soal, serta tidak menuliskan kesimpulan jawaban akhir dalam bentuk kalimat. Hal tersebut disebabkan karena lupa dan siswa tidak terbiasa menuliskan kesimpulan.

Berdasarkan analisis hasil tes dan wawancara siswa menunjukkan bahwa kesalahan penulisan jawaban akhir yang dilakukan siswa disebabkan karena:

a. Siswa kurang teliti dalam mengubah hasil yang diperoleh dalam bentuk kata-kata.

b. Kemampuan siswa dalam memahami perintah masih kurang, sehingga menyebabkan kesalahan dalam menentukan apa yang seharusnya disimpulkan.

c. Siswa tidak terbiasa menuliskan kesimpulan.

\section{PENUTUP}

\section{Simpulan}

Kesimpulan yang dapat dikemukakan pada penelitian ini adalah sebagai berikut :

\section{Tahap Membaca}

Siswa dapat membaca dengan lancar, hal ini dikarenakan bentuk soal merupakan soal cerita yang menggunakan Bahasa Indonesia. Kata-kata yang digunakan dalam soal juga tidakada yang menggunakan istilah asing yang menyulitkan pengucapan siswa. Dalam hal ini peneliti menetapkan pada tahap membaca tidak ada permaalahan dant idak menghitung persentase kesalahan yang dilakukan siswa.

\section{Tahap Pemahaman}

Kesalahan yang paling banyak dilakukan siswa yaitu pada tahap pemahaman dengan persentase sebesar $37.15 \%$.Siswa melakukan kesalahan pada saat mengidentifikasi perintah soal, sehingga salah dalam menentukan apa yang diketahui dan apa yang ditanyakan dalam soal serta melakukan kesalahan dalam mengubah konteks masalah soal cerita menjadi bahasa sendiri yang berpengaruh pada proses penyelesaian soal. Kesalahan memahami soal yang ditemukan meliputi:

a. Tidak menuliskan apa yang diketahui

b. Menuliskan apa yang diketahui tidak sesuai dengan permasalahan soal

c. Menuliskan apa yang ditanyakan tidak sesaui dengan permasalahan soal

d. Tidak menuliskan apa yang ditanyakan pada soal

\section{Tahap Transformasi}

Selanjutnya kesalahan yang dilakukan siswa yaitu kesalahan transformasi dengan persentase $13.04 \%$. Pada jenis kesalahan ini siswa tidak dapat menerjemahkan kesalahannya dan mentransformasiin formasi yang ada pada soal ke dalam bentuk kalimat matematika, sertakurangnya pemahaman untuk menggunakan metode yang akan digunakan.

\section{Tahap Keterampilan Proses}

Kesalahan yang dilakukan siswa pada tahap keterampilan proses yaitu dengan persentase $20.94 \%$. Pada jenis kesalahan ini siswa masih melakukan kesalahan dalam proses perhitungan,diantaranya pada saat memindahkan suku keruas yang berbeda serta dalam menjumlahkan dua suku yang variabelnya sama. Selain itu siswa juga melakukan kesalahan dalam proses eliminasi dan substitusi yaitu ketika melakukan operasi perkalian, penjumlahan, dan pengurangan serta kurangnya pemahaman operasi apa yang akan digunakan.

\section{Tahap Penulisan Jawaban Akhir}

Kesalahan selanjutnya yaitu kesalahan penulisan jawaban akhir dengan persentase $28.85 \%$. Dalam hal ini siswa tidak menuliskan kesimpulan dari solusi yang diperoleh dengan tepat, bahkan sebagian siswa tidak mengubah solusi yang diperoleh ke dalam bentuk kalimat sesuai dengan permasalahan nyata yang diketahui pada soal. Secara umum peneliti mengambil kesimpulan yaitu siswa masih banyak melakukan kesalahan pemahaman dalam menyelesaikan soal cerita persamaan linear tiga variable secara umum disebabkan karena pemahaman siswa yang kurang dalam mengidentifikasi apa yang diketahui dan apa yang ditanyakan pada soal. Faktor lain yang menjadi penyebab siswa melakukan kesalahan meliputi:

a. Siswa tidak membaca dan memahami soal dengan teliti

b. Kemampuan siswa yang rendah dalam menentukan apa yang diketahui dan apa yang ditanyakan pada soal 
c. Tingkat kreativita ssiswa yang kurang dalam mengidentifikasi masalah nyata ke dalam bentuk metematika

d. Kurangnya pemahaman tentang tahapan pada proses menyelesaikan soal.

\section{Saran}

Berdasaarkan hasil penelitian di atas maka dapat disaarankan :

1. Siswa diharapkan mempelajari materi persamaan linear dengan baik agar memiliki kemampuan dalam menyelesaikan soal cerita yang biasa dikerjakan dengan metode yang diajarkan pada materi persamaan linear tigavaribel.

2. Guru diharapkan lebih sering mengenalkan kalimat matematika supaya siswa terbiasa dengan kaliamat matematika tersebut sehingga katika menghadapi permaalahan matematika, siswa secara otomatis

\section{DAFTAR PUSTAKA}

Arifin, Zainal. 2013. EvaluasiPembelajaran Bandung:PT. REMAJA ROSDAKARYA

Arikunto, Suharsimi. 2012. DasarDasarEvaluasiPendidikan. Jakarta : PT. BUMI AKSARA

Haryati, Tuti. 2015. "Analisis Kesalahan Siswa Smp Kelas Vii Dalam Menyelesaikan Soal Cerita Pemecahan Masalah Berdasarkan Prosedur Newman”. Dalam Skripsi, Online, http://lib.unnes.ac.id/22328/1/4101411066-s.pdf, diunduh 20 Juli 2018 pukul 20.30

Moleong, J. 2010. Metodologi Penilitian Kualitatif. Edisi revisi. Bandung: PT Remaja Rosdakarya.

Rokhimah, Siti. 2015. “Analisis Kesalahan Siswa Dalam Menyelesaikan Soal Cerita Matematika Materi Aritmetika Sosial Kelas Vii Berdasarkan Prosedur Newman”. Dalam Skripsi, Online, http://lib.unnes.ac.id/21563/1/4101411135-S.pdf, diunduh 20 Juli 2018 pukul 20.30

Trapsilo, Tarsisius Eko Bagus. 2016. “Analisis Kesalahan Siswa Menurut Teori Newman Dalam Menyelesaikan Soal-Soal Cerita Materi Persamaan Linier Dua Variabel Pada Siswa Kelas Ix Smp N 1 Banyubiru". Dalam Jurnal, Online,

http://repository.uksw.edu/bitstream/123456789/ 9775/2/T1_202010039_Full\%20text.pdf, diunduh 4 gustus 2018 pukul 15.15 langsung dapat menentukan permasalahan yang dimaksud pada soal cerita dan tidak menimbulkan salah tafsir. Guru membiasakan siswa untuk menjawab dengan lengkap soa-soal cerita yang berkaitan dengan kehidupan sehari-hari.

3. Sebaiknya guru lebih sering memberikan latihan soal-soal cerita yang bervariasi. Mulai dari soalcerita yang sederhana sampai dengan soal-soal cerita yang lebih kompleks dengan menekankan pada penggunaan langkah-langkah penyelesaian soal cerita agar siswa lebih terlatih dalam menyelesaikan soal cerita agar lebih sistematis.

4. Guru diharapkan menampung keluhan-keluhan siswa dalam menyelesaikan soal cerita yang berkaitan dengan kehidupan sehari-hari dan membantuk kesulitan-kesulitan yang dialami oleh siswa agar dapat dikurangi. 